\title{
A Sociedade de Resistência dos Trabalhadores em Trapiche e Café no Rio de Janeiro: novos questionamentos para incontornáveis debates (1904-1913)
}

\section{The Sociedade de Resistência dos Trabalhadores em Trapiche e Café: new interrogations for crucial debates}

\section{Lívia Cintra Berdu*}

Resumo: O período compreendido entre as últimas décadas do século XIX e o início do século XX nas principais cidades do Brasil - incluindo o Rio de Janeiro - é marcado por uma ebulição política e um intenso processo de conscientização dos trabalhadores acerca de suas condições de vida e trabalho. Nesse contexto, a zona portuária da cidade consistia num dos principais espaços de articulação dos trabalhadores e tinha a Sociedade de Resistência dos Trabalhadores em Trapiche e Café como um grande exemplo de ferramenta para sua organização. Tal entidade possuía diversos traços advindos do período escravista, seja na composição étnico-racial de seus associados ou em determinados elementos relacionados à organização desses sujeitos. Propomos, contudo, uma reaproximação do tema a partir de novas fontes no intuito de buscar novos questionamentos e suscitar novas reflexões, de forma a captar possíveis convergências entre as heranças provindas dos trabalhadores escravizados e suas formas de organização, por um lado, assim como novas perspectivas ideológicas oriundas das lutas dos trabalhadores europeus que se forjavam, por outro. Nesse sentido, podemos identificar em tal cenário bastante heterogêneo alguns elementos de conflito entre os trabalhadores, mas, também, diversos aspectos de solidariedade de classe entre eles.

Palavras-chave: Trabalhadores; Sociedade Resistência; Rio de Janeiro.

Abstract: The period between the last decades of $19^{\text {th }}$ century and first years of the $20^{\text {th }}$ century on Brasil's principal cities - including Rio de Janeiro - is characterized by a political

Doutoranda em História Social na Universidade Federal Fluminense (UFF). E-mail: livia_berdu@hotmail.com. ORCID: https://orcid.org/0000-0003-3006-0170. 
boiling and an intense consciousness process of these workers about their life and work conditions. In this context, the city's port area consisted in one of the principal spaces of the workers articulation and had the Sociedade Resistência dos Trabalhadores em Trapiche e Café like a big example of instrument for their organization, beyond it possess a number of traits originated in slave period, according to ethnic and racial composition of its members, or in determined elements related on these subjects organization. This article propose however, a new approach in this subject using new sources in a intent of searching new interrogations and raise new reflections, in a way to capture possible combinations between the slaved workers legacy and their organization ways on one hand, and new ideological perspectives originated by the Europeans workers struggles that was being shaped, on the other. In these terms, we can identify on that heterogeneous scenario, some conflict elements between the workers, but also, different class solidarity aspects among them.

Keywords: Workers; Sociedade Resistência; Rio de Janeiro.

\section{Os primeiros passos da entidade}

D URANTE AS PRIMEIRAS DÉCADAS do século XIX, o café consistia no principal artigo de exportação do Brasil, fazendo com que o desenvolvimento das atividades portuárias na cidade do Rio de Janeiro estivesse intimamente ligado à comercialização desse produto. Por outro lado, o tráfico de escravizados negros africanos acompanhava o desenvolvimento de seu cultivo, já que a lavoura cafeeira era baseada em grande parte na mão de obra escrava, implicando assim numa grande concentração de trabalhadores negros - escravizados ou livres - na região do porto da cidade.

Já durante o Censo de 1872, ainda durante a escravidão, a população da zona portuária representava $30,8 \%$ (84.699) da população total da cidade, que era de 274.972 habitantes. Já em 1890, dois anos após a abolição, essa proporção caiu para 26\% (135.896) do total de 522.651 pessoas na cidade; e em 1906, representava 20\% (170.342) de 811.443 habitantes. ${ }^{1}$ Embora a proporção tenha caído no decorrer desses anos, a população absoluta cresceu na região na medida em que ali se instalaram os imigrantes que chegavam na cidade, especialmente espanhóis e portugueses.

Apesar da composição étnico-racial da zona portuária ser bastante heterogênea, entre o final do século XIX e início do século XX, a presença da população negra constituía ainda um traço marcante na região. Em 1890, a área concentrava o maior contingente de negros africanos da cidade (sendo $27 \%$ do total) e, ainda nesse ano, o percentual de negros (africanos e brasileiros) na região era maior do que a da cidade como um todo, sendo $34 \%$ da população em Santa Rita (antiga freguesia pertencente à zona portuária), enquanto o total da quantidade de negros na cidade era de $28,9 \% .^{2}$ Esse dado evidencia como a escravidão negra imprimiu contornos bastante específicos na história da cidade e na região mesmo após a abolição,

1 BRASIL. Ministério da Agricultura, Indústria e Comércio. Diretoria Geral de Estatística. Censos de 1872, 1890, 1906.

2 CRUZ, Maria Cecília Velasco e. Virando o jogo: estivadores e carregadores no Rio de Janeiro da Primeira República. Tese (Doutorado em História) - Faculdade de Filosofia, Letras e Ciências Humanas, Universidade de São Paulo, São Paulo,1998, p. 231. 
além das várias práticas culturais ligadas à tradição e cultura negra africana, como a capoeira, o jongo, o samba, o carnaval de rua e o candomblé, que se faziam fortemente presentes no local. Tais práticas, especialmente as religiões de matriz africana, eram também formas de garantir os territórios e o pertencimento dos espaços.

Assim, para além da esfera do trabalho, todos esses ambientes, junto aos inúmeros botequins e bares existentes no entorno, consistiam em espaços que possibilitavam a socialização, aproximação e organização dos sujeitos que ali habitavam, trabalhavam ou frequentavam e que, em grande parte, eram os mesmos sujeitos. Por outro lado, esses espaços também permitiam constantes discussões, brigas e conflitos, que consistiam em mais um atrativo para a repressão policial republicana no local contra os ditos crimes de contravenção, como a vadiagem, a capoeiragem e a embriaguez.

Em relação à organização política nos espaços de trabalho, podemos compreender, através de pesquisas já feitas anteriormente, a interessante trajetória da União dos Operários Estivadores e sua grande influência na organização política e sindical de algumas categorias portuárias no Rio de Janeiro nos primeiros anos do século XX. Observamos, ainda, que os trabalhadores ligados ao café - responsáveis pelo carregamento, armazenamento e arrumação nos armazéns e trapiches - consistem no principal exemplo, apesar dos setores do carvão e foguistas também terem tido interferência dos estivadores em sua articulação.

Outro elemento a se destacar consiste no cenário político existente na cidade naquele período, onde distintas concepções ideológicas chegavam de outros cantos do mundo junto aos viajantes e imigrantes de outros países e regiões do Brasil, ampliando assim os horizontes de luta dos trabalhadores brasileiros, em especial os ligados ao porto. O socialismo e as teorias libertárias como o anarcossindicalismo já estavam presentes desde as últimas décadas do século XIX, tendo como representantes alguns nomes já conhecidos pela historiografia do trabalho, como França e Silva e Evaristo de Moraes, que influenciavam diretamente na organização e nas disputas existentes entre os assalariados e seus patrões, como ocorreu nas greves de 1903 e 1906 na cidade.

É nesse contexto que, no dia 9 de novembro de 1904, reunidos na sede da União dos Operários Estivadores, os trabalhadores fundaram a Sociedade União dos Trabalhadores de Café e tiraram uma direção de cinco sócios, dos quais três eram portugueses (o secretário-geral, o segundo-secretário e o tesoureiro) e os outros dois eram de origem desconhecida. Contudo, nessa primeira vez, a Sociedade não obteve sucesso.

Já em abril de 1905, nasceu, também na sede da União, uma associação de atuação mais ampla que a anterior, chamada "Sociedade de Resistência dos Trabalhadores em Trapiche e Café", com endereço na rua Marechal Floriano Peixoto, n. ${ }^{\circ} 20$, que abarcava os "trabalhadores de tropa", isto é, os operários diaristas ou tarefeiros empregados nas casas de café, trapiches e na carga e descarga de carroças, em turmas ou tropas comandadas por capitães. Até ser iniciada a greve no ano seguinte, em agosto de 1906, momento em que várias categorias do porto da cidade voltavam a se mobilizar, é possível conferir no periódico Correio da Manhã que os trabalhadores 
da sociedade se mantiveram ativos nesse intervalo, efetuando diversas reuniões em sua sede. ${ }^{3}$

A historiadora Maria Cecília Velasco e Cruz destaca que, diferentemente dos estivadores, que se organizaram pela base e em seguida encaixaram os contramestres, os trabalhadores de tropa sindicalizaram-se através da direção de um capitão, formalizando em uma instituição as bases informais das turmas de trabalho erguidas no tempo da escravidão. Com o surgimento da entidade, os capitães de tropa mantiveram sua posição particularizada no processo de trabalho, seguindo a mesma dinâmica de fazer a mediação entre patrões e o mercado, porém, com algumas alterações importantes. Com o processo de associação entre todos os trabalhadores, a mediação passou a se dar entre a empresa e a entidade, ou seja, entre os patrões e o coletivo organizado, que, através de um grupo de fiscais, encarregava-se da responsabilidade da escolha dos homens na "parede" ou "ponto". Assim, apesar de parecer contraditório, os capitães tiveram papel estratégico no processo de criação da sociedade. ${ }^{4}$

Um ponto importante a se destacar consiste nos estatutos aprovados pelos associados em 1905, que possuíam claros traços condizentes com aquele momento histórico em que passava a cidade do Rio de Janeiro, com o surgimento do movimento operário na cidade e especialmente na região portuária, que fervilhava. Um dos lemas da entidade era "um por todos e todos por um" e tinha como um de seus objetivos "a união de todos os trabalhadores", sem qualquer "distinção de nacionalidade, cor e religião", além de criar uma biblioteca para instrução de sócios, "para não obstruírem as ideias burguesas e as mistificações"; e também de "propagar as ideias socialistas em conferências na sede social ou reunião pública". ${ }^{5}$ Defendia também a pretensão de se "fundar uma caixa de resistência para auxiliar e defender seus associados em caso de greve ou quando se virem coagidos em sua liberdade em defesa da classe". 6

Já em seu novo estatuto de 1906, manteve as atribuições de auxílio mútuo -contemplando a geração de "aulas de instrução, jornal de propaganda, uma biblioteca", o fornecimento de "auxílios pecuniários aos sócios enfermos e funeral para os que falecerem dentro da capital ou em Niterói", sugerindo "fundar uma Caixa de resistência para auxiliar e defender os seus associados em caso de greve ou quando se virem coagidos em sua liberdade, em defesa da classe" e "prestar defesa gratuita e obrigatória, no caso de prisão, perseguição injusta e abusos de que seus associados possam ser vítimas". ${ }^{7}$

Embora no seu momento de fundação houvesse apenas 25 indivíduos reunidos em assembleia num universo amplo de trabalhadores do café, em poucos meses seus sócios se multiplicaram de forma intensa, chegando a cerca de 500 filiados no ano seguinte. Cândido Manoel Rodrigues, capitão de tropa das Docas Nacionais, negro e nascido em Macaé no ano

3 Constam em edições do Correio da Manhã, dos meses de outubro e novembro de 1905 e fevereiro, março, maio e junho de 1906, convites aos trabalhadores para se reunirem na sede da Sociedade Resistência.

4 CRUZ, Maria Cecília Velasco e. Tradições negras na formação de um sindicato: Sociedade de Resistência dos Trabalhadores em Trapiche e Café - Rio de Janeiro, 1900-1930. Afro-Ásia, Salvador n. 24, p. 243-290, p. 287, 2000.

5 CRUZ, Maria Cecília Velasco e. Cor, etnicidade e formação de classe no porto no Rio de Janeiro: a Sociedade de Resistência dos Trabalhadores em Trapiche e Café e o conflito de 1908. Revista USP, São Paulo, n. 68, dez.-fev., p. 194, 2005-2006.

6 ARANTES, Érika Bastos. O Porto Negro: trabalho, cultura e associativismo dos trabalhadores portuários no Rio de Janeiro na virada do XIX para o XX. Tese (Doutorado em História) - Instituto de Ciências Humanas e Filosofia, Universidade Federal Fluminense, Niterói, 2010, p. 72.

7 Ibidem, p. 72 
de 1869, foi um dos principais responsáveis pela fundação da entidade e nela estaria presente até muitos anos depois, inclusive disputando um cargo na direção durante as eleições de $1913 .^{8}$

Como já foi bastante enfatizado pela bibliografia do tema, a composição étnico-racial da Sociedade Resistência era bastante marcada pelo período da escravidão, ou seja, grande parte dos seus sócios eram negros, assim como os carregadores descritos pelos viajantes durante o século XIX, que em sua grande maioria eram escravizados ao ganho.

Cruz pôde efetuar uma consistente pesquisa através do cruzamento entre fontes às quais teve acesso, como as fichas ${ }^{9}$ dos primeiros sócios da União dos Operários Estivadores e da Sociedade de Resistência dos Trabalhadores em Trapiche e Café, bem como os registros da Casa de Detenção do mesmo período. Assim, a historiadora pôde observar que apenas $23,5 \%$ dos trabalhadores de tropa sócios da Resistência eram brancos, e destes, pouco mais da metade era composta de estrangeiros. Entre os negros, ${ }^{10}$ eram todos nascidos no Brasil com a exceção de um africano, o que nos permite pensar na possibilidade de muitos libertos e seus descendentes terem continuado nesse espaço de trabalho, como é comum na tradição portuária. ${ }^{11}$

A historiadora afirma que, apesar da composição étnico-racial da cidade e da região portuária como um todo terem se alterado profundamente nos momentos finais do século XIX e início do século $X X$, os trabalhadores portuários, e em especial as categorias envolvidas com o carrego e descarrego de produtos, a estiva, a arrumação dos mesmos nos trapiches e armazéns, possuíam uma composição majoritariamente negra. A autora destaca ainda sobre a Resistência:

Se a composição social da classe trabalhadora carioca foi refeita de modo radical com a chegada contínua dos imigrantes, o mesmo não ocorreu, pelo menos nas mesmas proporções, entre os operários do porto do Rio de Janeiro. (...) Os brasileiros e os pretos e pardos predominavam na força de trabalho portuária, tanto em terra como no mar. A Resistência era um reduto negro, indicando que os escravos e os homens livres de cor seguraram com unhas e dentes os seus postos de trabalho, apesar de terem sofrido a concorrência dos imigrantes, principalmente dos portugueses. ${ }^{12}$

Erika Arantes também aponta indícios nesse sentido a partir de dados colhidos na Casa de Detenção no período compreendido entre 1901 e 1910, o cruzamento com documentação relacionada aos sócios e posterior constatação de que a maioria dos trabalhadores portuários presos eram negros e pardos. ${ }^{13}$ Como coloca a autora, apesar desse elemento poder indicar apenas a repressão concentrada nos indivíduos que possuíam tal cor de pele, o perfil apontado pelas fontes condiz com aquele existente entre os trabalhadores da estiva e carregadores durante o século XIX. ${ }^{14}$

8 A Época, Rio de Janeiro, 18 mar. 1913.

9 A autora trabalha com amostras, analisando cerca de 353 fichas.

10 A autora utiliza os termos "pretos" e "pardos", conforme foi utilizado no Censo de 1872. Optamos pela utilização do termo "negro", de forma a abarcar todas as categorias que identifiquem pessoas "não brancas".

11 CRUZ, 2000, op. cit., p. 271.

12 CRUZ, 1998, op. cit., p. 233 e 234

13 A historiadora Erika Arantes também faz uso do termo "pardo", conforme foi utilizado no censo de 1872. Reafirmamos nosso uso do termo "negro", de forma a abarcar todas as categorias que identifiquem pessoas "não brancas".

14 ARANTES, op. cit., p. 44. 
Para além de tal composição entre os trabalhadores, a entidade possuía, ainda, elementos provindos da organização dos escravizados como, por exemplo, sua arrumação em filas durante o carrego do café, enquanto entoavam cantos do período escravista. Como já foi dito anteriormente, também as turmas de trabalho e a seleção de um capitão responsável pela mesma turma, também consistia em uma forma de seu arranjo naquela mesma época.

Ademais, a história da Sociedade Resistência possui outras características que saltam aos olhos dos pesquisadores sobre o mundo do trabalho e o movimento operário carioca na Primeira República, que consiste na sua sólida organização entre os operários de café e sua posição bastante ativa nas lutas cotidianas contra seus patrões. Além da greve geral ocorrida em 1903 na cidade do Rio de Janeiro, a greve de 1906 também foi expressão desses embates e consistiu numa dura batalha contra as forças policiais e o patronato, sendo bastante noticiada pela imprensa local. No manifesto reproduzido abaixo, escrito em 13 de agosto do mesmo ano pelo presidente da entidade naquele momento - Aristides Figueira de Souza -, se chama os trabalhadores para a luta, em um tom bastante combativo:

Aos trabalhadores em trapiche e café. Companheiros, Avante! O proletariado brasileiro não podia, por mais tempo, deixar de levantar os seus protestos, desde que o regime da injustiça social, da desigualdade de classe, não está limitado por fronteiras, senão que é universal. Ele quer dignificar-se, quer que o seu trabalho, única fonte de toda riqueza social, não represente mais, para ele, a miséria, e para os que nada fazem, a riqueza. Pois, companheiros, é chegado o momento de nós pedirmos o aumento de salário, porque o homem que trabalha tem o direito de contratar as condições que pode trabalhar, dando valor ao seu serviço mediante um acordo com os patrões. Pois nós somos os únicos que nem existem leis em nosso favor, mas sim, em favor dos patrões, dando plenos poderes de nos impor a tantos vexames a ponto de que quando nós queremos propor um acordo pedindo aumento, tendo por resposta navios, torpedeiras, Marinha e Polícia para nos intimidar e perdermos a coragem e o direito de puxar pelos nossos interesses. Pois, companheiros, tenham coragem de pedir o aumento de salários pois é um direito que nos assiste como trabalhador. A nossa conduta nos fortificará na luta, a nossa união nos dará vitória sem violência, no terreno em que nos coloca o interesse da nossa classe. Viva os Trabalhadores em Trapiche e Café! Viva a Greve Geral da Classe! ${ }^{15}$

O início da greve de 1906 se deu de fato na madrugada do dia 20 de agosto, quando no Jornal do Brasil foi noticiado que alguém havia sinalizado à polícia que, na hora de iniciar o trabalho de carga e descarga do café, os trabalhadores entrariam em greve nos trapiches localizados no bairro da Saúde. Na manhã seguinte, foi constatado nos armazéns de café que esses mesmos homens não responderam à chamada nos trapiches da Saúde, Docas Nacionais, Ordem, Frias, Rio de Janeiro, Ypiranga, Mauá, Costeira, Damião, Silvino, Marítima (seção de café) e Novo Comércio, que não puderam iniciar o serviço. Horas depois, cerca de 62 homens alheios ao trabalho portuário foram alocados nos quatro primeiros trapiches citados (a mando da Comissão das Obras do Porto), onde o trabalho foi então iniciado. Contudo, por volta de onze horas da manhã, as comissões de grevistas conquistaram a adesão desses

15 Artigo de jornal contido no caderno pertencente a Aristides Figueira de Souza. Não possui data ou nome do periódico de publicação. 
carregadores de café, e ao meio-dia o comércio do produto já estava parado em toda a praça do Rio de Janeiro. ${ }^{16}$

O motivo dos acontecimentos estava em um boletim colocado na sede da Sociedade Resistência, onde se lia a seguinte mensagem:

Por deliberação da assembleia geral extraordinária, efetuada a 19 do corrente, ficou resolvido que em vista de não ser atendido o pedido de 20 réis em caixas de batatas, e também de não ter sido aceito o companheiro encarregado do trabalho do trapiche da Saúde, a mesma resolveu por unanimidade de votos pedir aumentos de preços em todos os volumes e por dia, produzindo uma tabela que a mesma associação vai apresentar, sendo a tabela geral de preços para todos os trapiches e trabalhadores de café..$^{17}$

Com o acontecido, a entidade organizou a paralisação do trabalho, entrou em sessão permanente e a greve foi iniciada, incorporando tanto o setor cafeeiro quanto o trapicheiro. Porém, só o primeiro estava representado no Centro do Comércio de Café da cidade, enquanto vários comissários, ensacadores e exportadores também estavam próximos à Associação Comercial do Rio de Janeiro; e as firmas trapicheiras não estavam ligadas a nenhuma associação. Dessa forma, os associados reunidos na sede formulavam uma tabela salarial ampla, abrangendo todos os diferentes tipos de serviço feitos pelos trabalhadores de tropa. ${ }^{18}$

Após algumas reuniões, a tabela apresentada pelos trabalhadores foi aceita com algumas alterações e o fim da greve chegou a ser declarado, mas, no dia seguinte, algumas firmas que haviam assinado o termo não cumpriram o que concordaram. Além disso, quando os trabalhadores chegaram para iniciar o serviço, viram que homens estranhos já trabalhavam em duas importantes casas de café com a escolta de policiais. De volta à sede da Resistência, os grevistas concordaram em paralisar novamente a categoria, voltando ao trabalho apenas com a efetivação das condições já acordadas pelos patrões. Nesse momento, ganharam ainda o apoio dos estivadores, que entraram em greve no dia 23 de agosto. ${ }^{19}$

No dia 24, porém, surge uma tentativa de fragmentação do movimento por parte dos trapicheiros que, recusando propostas dos trabalhadores, ofereceram pagar mais $15 \%$ sobre os valores antigos, mas, em compensação, exigiam que os carregadores entrassem no interior dos navios atracados, fazendo assim o serviço executado pelos estivadores. O advogado da Resistência Evaristo de Moraes, assim como seu presidente Aristides de Souza, não aceitaram a contraproposta e, a partir daí, foi colocado um grande impasse. Com a posição inflexível dos trabalhadores, por um lado, e a pressão dos comerciantes de café, por outro, foi decidido pela divisão da tabela em dois blocos, deixando para ser discutido posteriormente com os estivadores a questão dos trapicheiros. Foi concordado, então, que o trabalho fosse retomado no dia seguinte, sem qualquer prejuízo para os estivadores. ${ }^{20}$

Em assembleia na sede da entidade, naquele mesmo dia, os trabalhadores souberam que a greve havia terminado no setor do café, mas que ainda estava indefinida a situação dos trapiches. Nessa mesma reunião, os grevistas recusaram de forma unânime a proposta dos trapicheiros e tentaram articular iniciativas para manter a greve, enquanto os estivadores

16 Jornal do Brasil (Operariado), Rio de Janeiro, 19 dez.1904, p. 2.

17 Jornal do Brasil, 21 ago. 1906, p. 3 apud CRUZ, 1998, op. cit., p. 278.

18 Ibidem, p. 278-279.

19 Ibidem, p. 280.

20 Ibidem, p. 281. 
resolveram apoiar materialmente o movimento e se propuseram ainda a construir uma greve geral, caso necessário. ${ }^{21}$

O presidente da Associação Comercial acionou então o chefe da polícia, alegando intransigência por parte dos operários dos trapiches e solicitando a liberdade de trabalho daqueles que optassem por trabalhar, o que significava, na prática, a repressão contra os grevistas. O chefe da polícia determinou a prisão imediata de qualquer indivíduo que impedisse os operários de trabalhar, enquanto os trabalhadores fizeram um "comício de solidariedade operária" em frente à sede da Resistência, onde declaravam publicamente estarem juntos aos estivadores, já que sua luta consistia na mesma luta dos carregadores. ${ }^{22}$

A partir desse momento, o movimento dividiu-se em várias frações contra os trapiches, e a repressão policial se intensificou cada vez mais contra os trabalhadores grevistas, se estendendo até meados de setembro, quando o movimento começou a se decidir pelo fim da greve. Grande parte das empresas consentia em pagar os $15 \%$ exigidos, mas mantinha a condição de que os "trabalhadores de carreto" entrassem nas embarcações, enquanto outras não aceitavam nem uma coisa nem outra. Contudo, os trapiches Reis, Comércio, Rio de Janeiro e Moinho Fluminense concordaram com as condições da Resistência desde o final de agosto e, portanto, voltaram a operar normalmente..$^{23}$

No dia 30 de agosto, o ministro da Indústria e dos Transportes determinou que os trapiches geridos pelo governo devessem começar a pagar os $15 \%$ reivindicados, e, alguns dias depois, o sindicato anunciava que voltara a funcionar. Aos poucos também voltavam os trapiches, que foram aceitando um por um as condições da Resistência, ou faliam. A polícia ia se recolhendo da região portuária e a imprensa não mais noticiou sobre a greve, até sua finalização por completo. ${ }^{24}$

O Correio da Manhã, no dia 14 de outubro de 1906, dedicou grande parte de seu espaço para uma matéria sobre a entidade e os resultados da greve, acompanhada de fotos da diretoria, do estandarte da associação e de parte dos associados:

Reproduzimos, hoje, as fotografias obtidas por nosso representante fotográfico no domingo último, por ocasião da festa de inauguração do estandarte dessa valorosa associação operária. Fundada a 15 de abril de 1905, sob os auspícios da União dos Estivadores, ganhou bem cedo vida própria e autônoma sob a hábil direção do seu presidente, Aristides Figueira de Souza, secundado por dignos companheiros diretores. Aumentou seu prestígio e valimento decretando greve geral nos trapiches e nas casas de café, em data de 13 de agosto último. Nesse trabalho (ilegível) eticamente auxiliado pelo advogado Evaristo de Moraes, a quem uma assembleia concedeu o título de sócio comum, por não querer o mesmo profissional honras nem distinções no seio das sociedades operárias. Presentemente, e em razão da greve, (ainda não de todo terminada) obtêm os carregadores - quase todos sócios da Resistência (como eles Ihe chamam) - salários relativamente elevados, gozando de regalias que nunca tiveram. Por isso mesmo, o número de sócios da Associação, que era de 900 no início da greve, é hoje de 2.423 , de um acordo com um pacto de solidariedade firmado entre as respectivas diretorias, por deliberações de assembleias gerais, são material e moralmente solidárias com a Associação e as (ilegível) dos Foguistas, dos

\footnotetext{
21 Ibidem, p. 281

22 Ibidem, p.282.

23 Ibidem, p.283.

24 Ibidem, p.283.
} 
Estivadores, dos Carvoeiros, dos Marinheiros e Remadores, das Costureiras de sacos e dos Carroceiros e Cocheiros. Constituem sua atual diretoria os trabalhadores em trapiche e café seguintes: Aristides Figueira de Souza, presidente; Valdemar José Cruz, $1^{\circ}$ secretário; Joaquim Ramos; Cyrillo de Lima, tesoureiro; Arthur de Paula Costa, procurador; e Rufino Ferreira da Luz, fiscal geral. Em cada trapiche ou casa de café coloca a sociedade um representante do trabalho, reconhecido pelo industrial que emprega a "tropa" e respeitado pelos companheiros, que a compõem. Para manter a boa ordem e a necessária disciplina, existem muitos fiscais que são também carregadores, usando uma chapa especial, que é o distintivo de sua categoria. A estes auxiliares do fiscal geral compete dar partes ou queixas, bem como resolver pequenos incidentes e aplainar dificuldades momentâneas e dúvidas entre operários ou com os patrões. Para os sócios desobedientes, faltosos ao cumprimento dos deveres sociais, bem como maus companheiros, há penas severamente aplicadas, que vão desde a tirada do cartão (que os impossibilita por alguns dias de trabalhar) até a expulsão da sociedade. As reclamações trazidas pelos comerciantes e industriais ao conhecimento do fiscal geral ou da diretoria são atendidas prontamente, bem como as dos operários, quando ofendidos em seus direitos. Enfim - é uma associação de gente laboriosa e honrada, que harmoniza os interesses do Capital com os do Trabalho e pode servir de exemplo a muitas outras. ${ }^{25}$

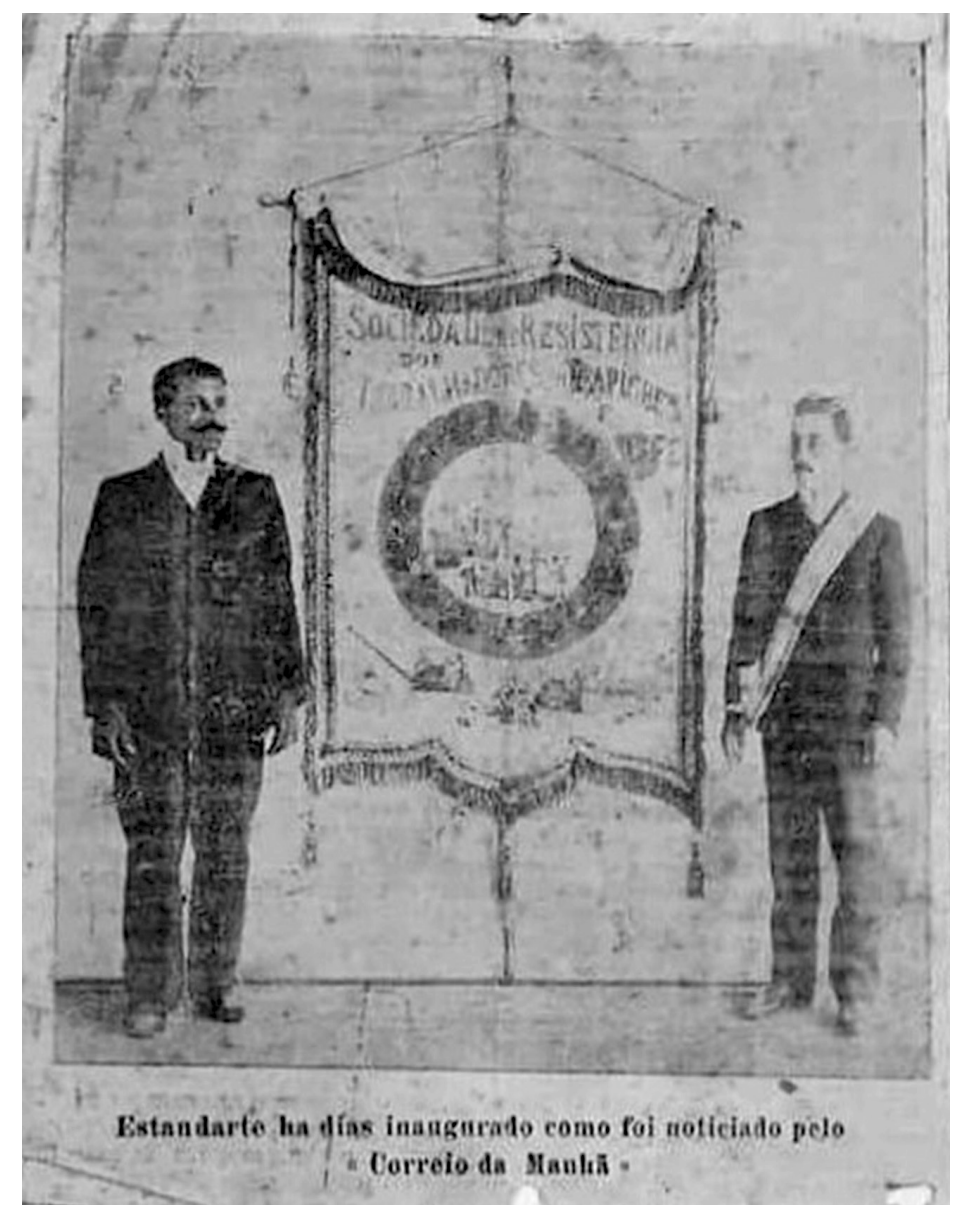

Legenda da foto: Estandarte há dias inaugurado como foi noticiado pelo Correio da Manhã.

Fonte: Correio da Manhã, 14 out. 1906.

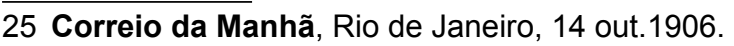




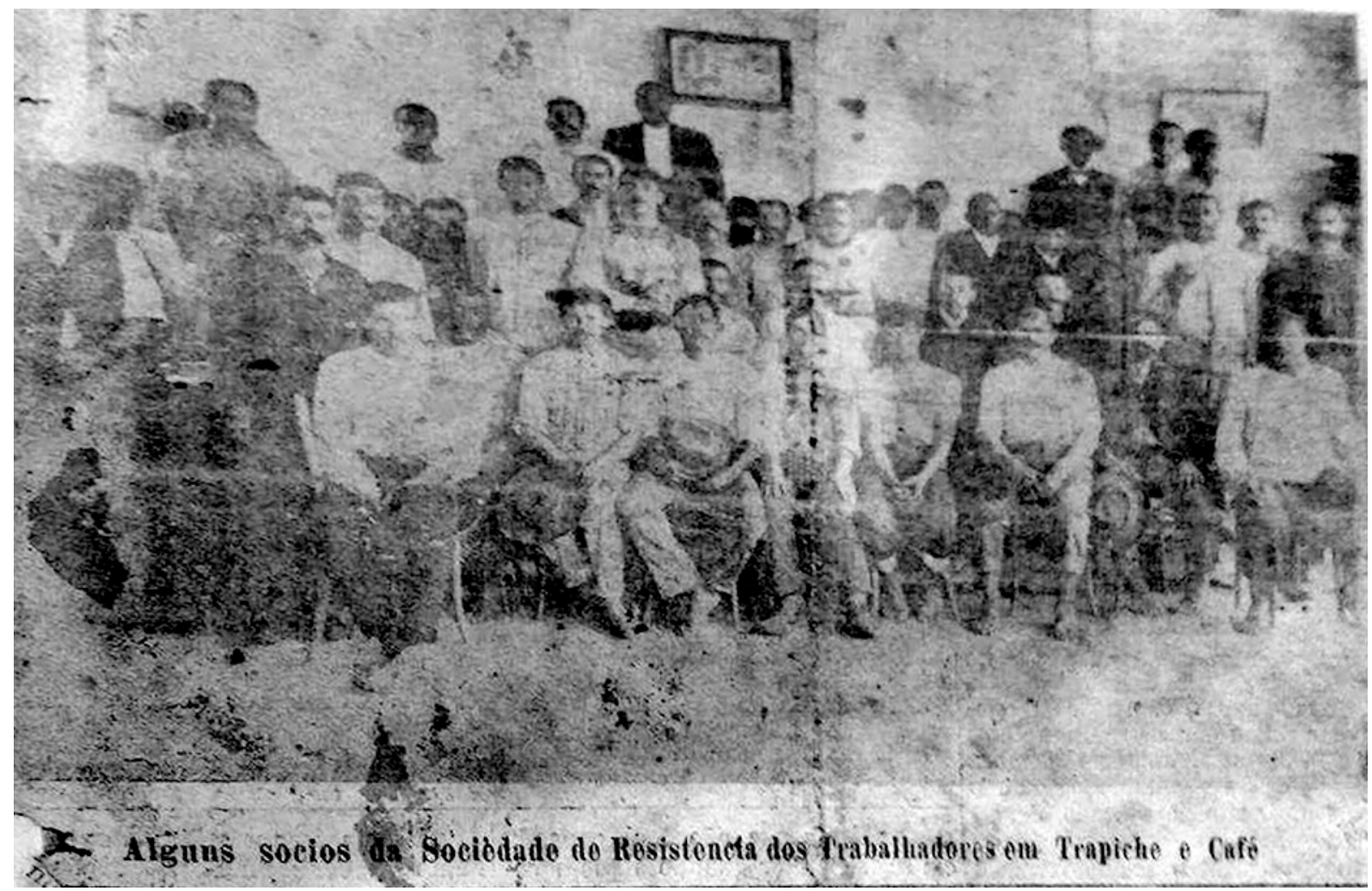

Legenda da foto: Alguns sócios da Sociedade de Resistência dos Trabalhadores em Trapiche e Café. Fonte: Correio da Manhã, 14 out. 1906.

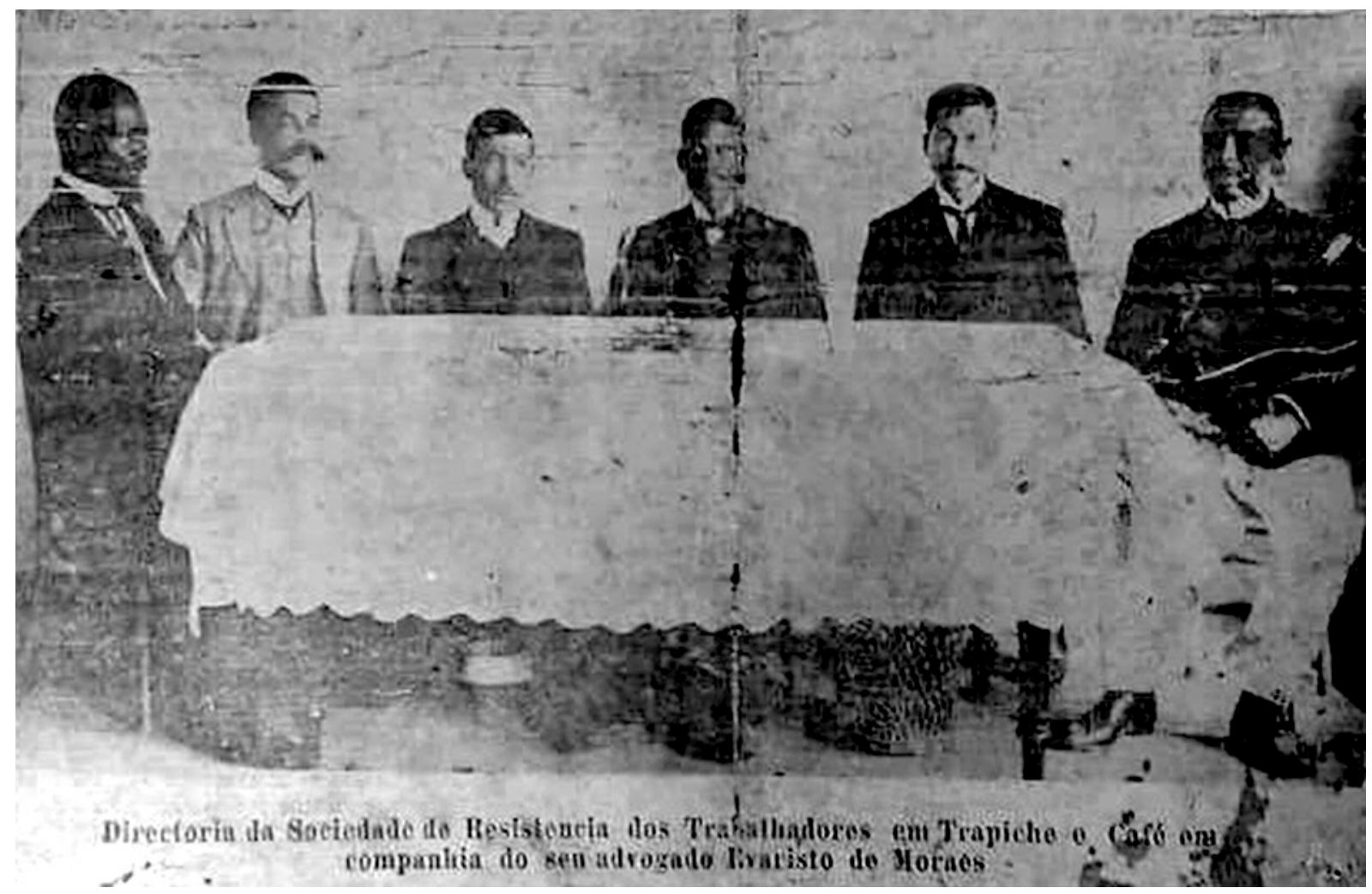

Legenda da foto: Diretoria da Sociedade de Resistência dos Trabalhadores em Trapiche e Café em companhia do seu advogado, Evaristo de Moraes.

Fonte: Correio da Manhã, 14 out. 1906. 
Já em janeiro de 1908, dois anos após a greve, a Resistência passa por uma alteração formal em seu nome, passando de uma associação de classe a um sindicato formal, e como era de se imaginar, esse fato provoca descontentamento no setor patronal do comércio de café, que não reconhecia a alteração. No dia 8 de outubro, no Correio da Manhã, é publicado um extenso artigo escrito pelo advogado Evaristo de Moraes a respeito desse embate:

(...) Os carregadores ocupados nos armazéns de café e nos trapiches tinham fundado, em 1905, uma associação de classe a que denominaram "Sociedade de Resistência dos Trabalhadores em Trapiche e Café". Foi esta associação que, a 10 de janeiro do corrente ano, resolveu, em assembleia, transformar-se em Sindicato, obedecendo a tendência geral do movimento operário em todo o mundo civilizado. Feita a instalação, foram remetidos os documentos exigidos por lei ao Exm. ${ }^{\circ}$ Sr. Procurador Geral da República, ao tabelionato de hipotecas e à Junta Comercial. Examinados os documentos pela Procuradoria da República, foi expressamente declarado que estava em condições legais de funcionamento a nova instituição. Representante legítimo da classe, era natural que o Sindicato procurasse, por todos os meios conciliatórios, obter a asseguração das vantagens já conseguidas, desde 1906, pela Sociedade de Resistência. Foi o que intentou, encontrando infelizmente da parte de alguns comerciantes a mais injustificada prevenção. Pouco conhecedores da organização industrial do nosso tempo e do valor que, por toda parte, vão tendo as coligações operárias, eles não querem, antes de tudo, reconhecer no sindicato uma personalidade jurídica, uma entidade coletiva, uma pessoa moral, com a necessária capacidade para tratar em nome dos seus consócios e por eles resolver, aliás protegendo, também, indiretamente os não associados. Uma das causas principais da reação, imprudentemente fomentada no seio do comércio, é a falta de compreensão da legalidade e dos fins honestos e lícitos do Sindicato. Essa ojeriza patronal se dirigia, ao princípio, contra a palavra Resistência, que soava a alguns ouvidos como uma voz de rebeldia e de desordem. Agora as prevenções de certa parte do comércio se acumulam em volta do SINDICATO, que parece espantar e causar pavor. Nem valeu para dissipar essa lamentável impressão a independente e criteriosa atitude do preclaro professor e jurista Souza Bandeira, advogado do Centro de Comércio de Café. Sabedor emérito dos progressos do Direito Industrial, conhecedor da legislação universal a esse respeito e como sincero democrata, o dr. Bandeira aconselhou ao Centro que abandonasse o princípio carrancista que animava alguns dos seus sócios e francamente entrasse em negociações com o Sindicato. Foi nesse sentido que a diretoria do Centro fez redigir, por seu advogado, a minuta de uma escritura, com a qual o Sindicato, sempre conciliador, se conformou. As grandes casas ensacadoras e exportadoras, em cujo seio há quem conheça a excelência da organização sindical - como existe na Alemanha, na Inglaterra e nos Estados Unidos - não fizeram a menor oposição à escritura, que seria o reconhecimento do Sindicato Operário. Há, porém, uma minoria reacionária que ainda quer guardar, no comércio de café, a tradição do tempo antigo, do tempo em que o trabalhador não tinha consciência dos seus direitos. Há, mesmo - para que não dizê-lo - quem, por educação e por índole escravocrática, ainda lamenta a gloriosa jornada de 13 de maio e mal consiga distinguir o salariado livre do mísero escravizado de outrora! Foi essa minoria que, por uma táctica cheia de egoísmo, e subjugou os espíritos, obrigou a diretoria a pedir demissão, desmoralizou o advogado e, correndo à polícia e ao governo, rompeu com o Sindicato. Nessa manobra ia (toda gente o sentia) a provocação da greve e o intuito, sem sequer disfarçado, de fundar outra associação operária, explorando ódios de raça... Desde sua primeira reunião, alguns patrões 
lembraram o alvitre de dividir os trabalhadores e atirá-los uns contra outros, diminuindo-Ihes o prestígio. Veremos o que têm maquinado. ${ }^{26}$

O texto deixa claro que o embate entre a entidade e a patronal se acirrou intensamente desde a greve de 1906, e, frente à profunda organização dos trabalhadores associados, a patronal teria usado de distintos mecanismos para sua desmobilização e divisão, gerando conflitos entre os trabalhadores e visando, ainda, à construção de outra associação ligada aos patrões. Outro elemento importante existente no texto consiste na pressão feita pelo patronato sobre a direção do sindicato, aparentemente obrigando-a a pedir demissão, além da desmoralização do próprio advogado frente aos trabalhadores. Sobre "o ódio de raça" citado por Evaristo, refere-se ao grande conflito ocorrido dentro do sindicato durante uma assembleia em 13 de maio de 1908, que mudaria os rumos da entidade, fazendo com que centenas de associados se desligassem da mesma. O ocorrido foi visto inicialmente como um conflito ocasionado por discriminações entre os próprios trabalhadores, mas, posteriormente, foi esclarecido e identificadas as suas motivações políticas. O evento foi extensamente explorado pela imprensa da época e pela historiografia do movimento operário do início do século. ${ }^{27}$

De qualquer forma, podemos verificar que a Sociedade Resistência consistia numa ferramenta fundamental de organização para os trabalhadores, a ponto de ser temida pelos patrões do café. Além disso, fica bastante expressa pelas palavras do advogado da entidade a percepção dos trabalhadores a respeito dos setores mais conservadores do patronato cafeeiro e suas ideias propagadas em relação aos trabalhadores negros. Sua consciência de que o sistema escravista havia enfim terminado e que tais sujeitos deveriam ser encarados como assalariados livres - ainda que não questionasse radicalmente a condição de explorados desses próprios assalariados - demonstra, sem dúvida, um processo de avanço de uma consciência de classe que se forjava através do forte embate com a classe capitalista do setor cafeeiro. Sobre esse processo de avanço de consciência rumo a rupturas mais radicais, em termos de projeto de sociedade, podemos ver no item a seguir.

\section{Influências socialistas na formação do sindicato}

COMO JÁ DESENVOLVIDO ANTERIORMENTE, a União dos Operários Estivadores e a Sociedade de Resistência tiveram fortes ligações com as ideias que se propagavam naquele período na cidade do Rio de Janeiro, fossem elas libertárias ou socialistas, e isso se refletia diretamente nas lutas travadas pelas duas entidades. Como coloca Velasco e Cruz:

Na fundação da Sociedade de Resistência dos Trabalhadores em Trapiche e Café há, portanto, projetos e dimensões de classe que ultrapassam os limites estreitos das ações e desejos dos capitães, alguns decerto ambiciosos e nada altruístas. Impossível dissociá-la, por conseguinte, do momento histórico em que ocorreu e da ebulição produzida entre os trabalhadores de tropa pelo surgimento de um movimento operário na cidade como um todo, e na região portuária especificamente. Os comícios frequentes, os cortejos operários com seus estandartes e música, a circulação de mensagens universalistas de

26 Correio da Manhã, Rio de Janeiro, 8 out. 1908, p. 1.

27 Para saber mais sobre o episódio, sugerimos a leitura do artigo "Cor, etnicidade e formação de classe no porto do Rio de Janeiro: a Sociedade de Resistência dos Trabalhadores em Trapiche e Café e o conflito de 1908", Revista USP, n. 68, 2005-2006. 
conteúdo socialista ou libertário, o esforço de mobilização dos estivadores e a força comunicativa das vitórias de inúmeras greves já acontecidas criaram as condições favoráveis para a elaboração de um projeto político alternativo à proletarização tangencial e à marginalização social que constituíam a dura realidade de vida daqueles homens. ${ }^{28}$

Ademais, tal aproximação nos parece ainda maior quando nos dedicamos a investigar a respeito de algumas de suas lideranças entre os primeiros integrantes da direção da entidade, que eram, eles próprios, militantes socialistas. Cabe destacar, como exemplo, o primeiro presidente Aristides Figueira de Souza: carregador, negro e, de acordo com o advogado da entidade, um corajoso e admirável representante dos trabalhadores associados. Em um texto manuscrito de Evaristo em maio de 1907, podemos ler um breve relato sobre a figura de Aristides durante as negociações na greve de 1906:

(...) Aristides Figueira de Sousa, que na presença de Sr. Chefe de Polícia, desembargador Espínola, pleiteou contra industriais e capitalistas, com rara habilidade, os direitos dos seus companheiros, semeando os esforços do advogado e fazendo a exposição dos fatos de acordo com a realidade, que bem e tristemente conhecia! O espetáculo foi deveras imponente: um pobre e humilde carregador, compenetrado dos seus deveres para com a classe, rodeado de patrões, alguns dos quais milionários, discutindo, reagindo, resistindo às ameaças e a mal disfarçadas tentativas de corrupção... ${ }^{29}$

Ao que parece, Aristides era um homem simples, porém bastante articulado politicamente e capaz de levar uma reunião de negociação com grandes empresários de forma bastante segura e determinada. Além disso, se lembrarmos do manifesto escrito por ele durante a greve de 1906 e reproduzido em algumas páginas anteriores, diríamos que se trata de um militante que tem entendimento não apenas das condições de trabalho e vida de sua própria categoria, mas possui, ainda, uma concepção socialista de mundo, partindo de noções como o internacionalismo e a fragmentação da sociedade em classes.

Apesar das distintas interpretações na historiografia do trabalho e do movimento operário acerca dos socialistas no Brasil durante o período da II Internacional - que se estendeu de 1889 até 1914 -, acreditamos que, olhar para esse momento histórico com as lentes dos dias de hoje, pode-se incorrer em alguns equívocos. Como pontua Cláudio Batalha, não cabe ao historiador que se reivindique de esquerda nos dias atuais atribuir critérios extemporâneos às correntes socialistas do passado, mas, sim, analisá-las e compreendê-las dentro do contexto em que se situavam, investigando, ainda, o peso que possuíam em sua época. ${ }^{30}$ Sobre as características já levantadas pela historiografia em relação a essa corrente, como o desconhecimento do marxismo, a incompreensão da realidade brasileira, a falta de base operária e o consequente apoio a setores da classe média e a pequenos burgueses, o autor assinala ainda que:

28 CRUZ, 2000, op. cit., p. 287.

29 Trata-se de um caderno existente ainda hoje no atual "Sindicato dos Portuários Avulsos em Capatazia e Arrumadores no Comércio Armazenador no Município do Rio de Janeiro". O caderno pertencia ao próprio Aristides Figueira de Souza e, além do texto manuscrito do advogado, possui recortes de jornais e anotações do primeiro presidente da associação.

30 BATALHA, Cláudio. O socialismo no Brasil na época da II Internacional: uma revisão de algumas interpretações correntes. In: XV Encontro Anual da ANPOCS, 1991, Caxambu/MG. Anais... São Paulo: ANPOCS, 1991, p. $1-26$, p. 2. 
Os socialistas brasileiros que atuaram na última década do século XIX e nos primeiros anos deste século podem não ser marxistas pelos critérios de hoje, mas seriam classificados como tais pelos critérios de seu tempo. ${ }^{31}$

Nesse sentido, as origens e a composição dos primeiros grupos socialistas nesse período, que estavam diretamente ligadas aos movimentos abolicionista e republicano, consistiam, talvez, naquilo que poderia ser chamado de uma "ala esquerda", ou o que existia de mais avançado naquele contexto, onde existiam setores que percebiam que a República não atenderia aos anseios da classe trabalhadora. ${ }^{32}$

Quanto ao discurso que utiliza Aristides para chamar a categoria a fortalecer o movimento e lutar por melhores salários e condições de vida, além de romper com as fronteiras impostas ao proletariado, demonstra que os trabalhadores portuários tinham uma atuação política combativa, além de um alto nível de solidariedade de classe expresso na greve de 1906 entre carregadores, estivadores e arrumadores.

Contudo, apesar de bastante admirado por Evaristo de Moraes, advogado e militante socialista bastante conhecido no movimento operário carioca no início do século $X X$, o presidente teve, provavelmente, desavenças com a entidade, as quais o colocaram em posição duvidosa na visão dos trabalhadores. No Correio da Manhã do dia 18 de agosto de 1907, apenas três meses após o texto do advogado, é emitida uma pequena nota no Correio da Manhã a respeito do sindicato, anunciando:

Por ordem da assembleia geral ordinária realizada em 10 do corrente, foi expulso pela segunda vez desta associação o Sr. Aristides Figueira de Souza, em vista de que o mesmo é pernicioso à classe e como tal não pode fazer parte desta associação. ${ }^{33}$

É bastante curioso que haja tal desarmonia entre a personalidade descrita por Evaristo e o trabalhador mencionado na nota anterior, considerando que o termo "pernicioso para a classe" possui carga bastante pesada, quanto mais se tratando de um membro expulso pela segunda vez da associação através do voto dos trabalhadores em assembleia. Todavia, tal expulsão pode estar relacionada à tática de pressão sobre as lideranças da entidade por parte do patronato após a greve, como explicitou Evaristo em texto anterior.

É uma pena, no entanto, o fato de que as historiadoras Maria Cecília Velasco e Erika Arantes - as duas principais pesquisadoras que se debruçaram sobre as fontes ligadas à história da Resistência - sequer terem mencionado o nome de Aristides em seus trabalhos, uma vez que se tratava da principal figura de liderança da associação no momento de sua criação. Ao longo da pesquisa efetuada nos periódicos e em material consultado no atual "Sindicato dos Portuários Avulsos em Capatazia e Arrumadores no Comércio Armazenador no Município do Rio de Janeiro", pudemos observar que esse trabalhador consistia num personagem importante nos primeiros momentos da história da entidade.

Em um caderno pertencente ao próprio Aristides, também é possível ver uma notícia do jornal $A$ Época, do dia 6 de novembro de 1912, em sua defesa, apesar de não constar o

\footnotetext{
31 BATALHA, Cláudio. A difusão do marxismo e os socialistas brasileiros na virada do século XIX In: MORAES, João Quartim (org.). História do marxismo no Brasil, v. II. Campinas, Unicamp, 1995, p. 11-44, p. 11.

32 Ibidem, p. 28.

33 Correio da Manhã, Rio de Janeiro, 18 ago. 1907, edição 04022.
} 
motivo das acusações de cinco anos antes da publicação. Acima do recorte de jornal, Aristides escreve à mão a seguinte legenda:

Retrato tirado e publicado pelo "Época" de 6 de Novembro de 1912 e de Aristides Figueira de Sousa, rua Martha da Rocha, s/n., Pilares, na ocasião que o Sr. Antônio Augusto Pinto Machado tratava de organizar o " 4 " Congresso Operário Brasileiro" realizado nesta Capital Federal de 7 a 13 de Novembro de 1912, no Palácio Monroe. Sendo presidente da República o marechal Hermes Rodrigues da Fonseca e Inspetor da Guarda Civil coronel Pedro (ilegível) Campos e chefe de Polícia Dr. Belizário Távora do qual solicita a minha exoneração da Guarda Civil de $2^{\mathrm{a}}$ classe sob o número 75 a 8 de setembro de $1912 .{ }^{34}$

Acompanhado do retrato de Aristides, seguiam os dizeres do jornal:

O retrato que hoje damos acima é o de um companheiro dos mais distintos, no momento, do meio do operariado desta cidade, onde é com justiça estimado. Foi o principal fundador da Sociedade de Resistência dos Trabalhadores em Trapiche e Café e foi o seu primeiro presidente. A sua ação naquele meio foi tão criteriosa, que falsos amigos do operariado, vendo a simpatia de que ele ali gozava e conhecendo nele um caráter sincero, incapaz de traficar com a sua associação e com seus companheiros, moveram-lhe uma guerra perversa que o obrigaram a mudar de vida, pois não podia trabalhar entre seus antigos companheiros que, movidos pela perversidade dos maus companheiros, não o deixaram trabalhar. Foi ser guarda civil e, tempos depois, fundou a Liga do Operariado do Distrito Federal com o redator dessa coluna, com Figueiredo do Albuquerque e Isaías do Amaral. Na fundação dessa Liga, foi encontrar a sua antiga S. de R. dos T. em Trapiche e Café quase dissolvida e meteu mãos à obra, ajudando-a também a erguer-se, o que conseguiu com os poucos companheiros que ainda encontrou. Deixou a Guarda Civil e veio de novo para o nosso meio, e ei-lo ali a trabalhar para a Liga e para a organização do $4^{\circ}$ Congresso Operário Brasileiro. Trabalhador infatigável, companheiro sincero, seria grave injustiça, no momento em que sua antiga Sociedade de Resistência e a sua Liga do Operariado do Distrito Federal se erguem no meio do operariado brasileiro, deixando de mencionar o seu nome nessas colunas como um dos que mais se tem dedicado a esse belo empreendimento. É o que fazemos no leal companheiro, com o preito da sinceridade que a ele nos prende. ${ }^{35}$

É importante demarcar que o jornal A Época foi lançado em 31 de julho de 1912, e tinha uma linha política abertamente contra o governo do presidente marechal Hermes da Fonseca (1910-1914) e contra, portanto, o Partido Republicano Conservador (PRC) e a imprensa que o bajulava. Mariano Garcia, ${ }^{36}$ militante socialista conhecido pela historiografia do movimento operário carioca na Primeira República, era redator da seção "Coluna Operária" desse mesmo jornal e, junto ao próprio Aristides e a Antônio Augusto Pinto Machado, fundaram a Liga do Operariado do Distrito Federal por volta de 1912.37

34 Caderno de memórias pertencente a Aristides Figueira de Sousa, que se encontra no atual Sindicato dos Portuários Avulsos em Capatazia e Arrumadores no Comércio Armazenador no Município do Rio de Janeiro.

35 Caderno de memórias pertencente a Aristides Figueira de Sousa. Não foi encontrada a matéria no jornal A Época na data referida, porém acreditamos que a nota teria sido escrita por Antônio Augusto Pinto Machado.

36 Para saber mais sobre a trajetória do militante socialista Mariano Garcia, ver: TERRA, Paulo Cruz, Cidadania e trabalhadores: cocheiros e carroceiros no Rio de Janeiro (1870-1906) Tese (Doutorado em História) Instituto de Ciências Humanas e Filosofia, Universidade Federal Fluminense, Niterói: 2012; BATALHA, Cláudio. A difusão do marxismo e os socialistas brasileiros na virada do século XIX In: MORAES, João Quartim (org.). História do marxismo no Brasil, vol. II. Campinas, Unicamp, 1995.

37 Parte do estatuto da Liga do Operariado do Distrito Federal pode ser encontrada na edição de número 00185 
Investigando mais a respeito desses militantes no jornal $A$ Época, pudemos ver que os três apareciam também com frequência ligados à Confederação Brasileira do Trabalho e à Comissão da União dos Inquilinos, além de Aristides constar como o responsável pela publicação de um jornal chamado $A$ Voz do Operário também no mesmo ano. No texto abaixo, escrito por ele no jornal $A$ Época, do dia 15 de janeiro de 1913, logo abaixo da coluna de Mariano Garcia, Aristides argumenta com um tom bastante engajado - condizente com o de um dirigente sindical - sobre a necessidade dos trabalhadores se mobilizarem, além de falar sobre a lei de deportação dos estrangeiros ${ }^{38}$ que se envolvessem na política local. Com o título: "Quem tem razão? - A reação é necessária", escreve:

O que presentemente se passa no Brasil, passa-se em toda parte do mundo, porque existem explorados e exploradores. Não pode deixar de merecer nossa atenção o pouco caso com que os grandes senhores, absolutos dirigentes desta infeliz terra, têm por todos nós operários e proletários que vivemos exclusivamente do pão de cada dia, ganho com os maiores sacrifícios. Que fazem ou esperam os homens que mandamos ao parlamento? Alguém de boa-fé poderia dizer que temos um parlamento como o que possuímos no regime monárquico? Ninguém. Em todos os tempos, aqui e em toda parte do mundo, os representantes da Nação são eleitos pela soberania popular e, quando se sentam em suas cadeiras, fazem alguma coisa pelos que os elegeram, honram o seu mandato. Hoje, os que nos representam, que são os representantes da Nação e do município, só tratam dos seus interesses particulares, não são capazes de fazerem uma lei que preste em nosso benefício. Não estão vendo, além de tudo isso, que não querem que reclamemos pelos nossos direitos e que, ao contrário disso, só legislam contra nós que somos os fatores do progresso e da grandeza nacional? Querem mais esses representantes? Essa lei de expulsão de estrangeiros abrange os brasileiros, e estes em situação pior, porque serão enviados para o Acre ou para Ilha das Cobras por qualquer falta que cometam. E então? Que fazemos que não reagimos contra essa lei? Estão dormindo ou com medo de protestar contra essa lei? Devemos nos agitar, e as classes em geral, e protestar contra essa lei, porque com o medo e com a covardia nada se obtém. Não quero dizer que devemos perturbar a ordem pública, não; o que queremos é que protestemos todos dentro do justo e do razoável. A felicidade de um povo é feita por si mesmo, e dos poderes constituídos da Nação nada podemos esperar senão a tirania e a opressão. Para onde serão expulsos esses nossos companheiros que para aqui vêm trabalhar e contribuem com os seus braços para a grandeza de nossa terra? Tanto no Brasil como em outra qualquer parte do mundo, o trabalhador está sempre em sua terra; tem direito a viver, porque trabalha e as terras só são divididas pelas águas que as cercam, e, em toda parte se nasce, vive e morre. Estão vendo os companheiros que os homens que legislam e que governam não ligam a menor importância aos que trabalham, e esse operariado não pode ser indiferente a tantos sofrimentos, a tantas injustiças e opressões. Tudo quanto nos é imprescindível a nossa subsistência está ficando pela hora da morte e em pouco estaremos reduzidos à maior desgraça, trancados na burra do capitalista a nossa vida, ficando cada vez mais escravizados. A justiça nos abandonou, enganando-nos. É preciso reagir. ${ }^{39}$

do jornal A Época, de 31 jan. 1913.

38 Trata-se do Decreto $n^{\circ} 1.641$, aprovado em 7 de janeiro de 1907, de autoria do então senador Adolpho Affonso da Silva Gordo, que ficaria conhecido como "Lei Adolpho Gordo" ou simplesmente "Lei Gordo". O decreto foi promulgado como lei complementar à Constituição Federal, objetivando impor as regras que permitiam a expulsão de estrangeiros pelo Poder Executivo. Em 1913 a lei é reformulada visando uma maior perseguição aos estrangeiros que se envolvessem com a movimentação política no Brasil.

39 A Época, Rio de Janeiro, 15 jan. 1913. 
Apesar de algumas contradições em seu discurso, além de uma certa defesa da monarquia como podemos notar no texto, temos aqui mais evidências de que o primeiro presidente da Sociedade Resistência mantinha estreitas relações com militantes socialistas da época, como Mariano Garcia, Evaristo de Moraes, Antônio Augusto Pinto Machado, e que o próprio Aristides era, sem dúvida, um militante socialista com uma sólida trajetória de atuação, após passar pela direção do sindicato. Infelizmente não possuímos registros de sua vida e trajetória política antes de 1905 - ano em que a Resistência é fundada -, mas podemos levantar a hipótese de Aristides já ser atuante antes mesmo da fundação da entidade. Apesar de tais apontamentos não aparecerem nas pesquisas anteriormente realizadas a respeito da Resistência, acreditamos que esse é um ponto crucial que merece ser refletido de forma mais detida em pesquisas futuras.

Cabe enfatizar, entretanto, que de qualquer forma o processo de fundação do sindicato teve fortes influências de cunho socialista, para além dos vários elementos de continuidade da organização já existente entre os escravizados ao ganho nesse setor de trabalho. O grande desafio seja, talvez, encontrar um equilíbrio entre a noção já exposta pela historiografia do trabalho, onde é colocada uma predominância da interferência imigrante na construção do movimento operário do início do século XX e, por outro lado, o legado de luta e resistência que deixaram os trabalhadores escravizados.

O que pudemos constatar, dentro dos limites do trabalho aqui proposto, é que, após a expulsão de Aristides em 1907, houve várias investidas do advogado Evaristo de Moraes defendendo-o publicamente, o que também poderia significar uma tentativa de sua própria defesa, já que pouco tempo depois - em março de 1909 - Evaristo também não seria mais o advogado oficial da Resistência. ${ }^{40}$ Além disso, pudemos observar que, em 16 de março de 1913, ocorrem novas eleições para a direção do sindicato; e apesar de Aristides ter concorrido novamente ao posto de presidente, obteve 121 votos e não foi eleito. ${ }^{41}$ Evidentemente esse fato demonstra que, mesmo após a expulsão, o carregador pôde voltar a ser sócio da entidade, o que pode ter ocorrido após esclarecimentos posteriores, dos quais não temos conhecimento. O que pudemos encontrar no mesmo periódico foi uma espécie de defesa de Aristides por parte de Evaristo poucos dias após as eleições citadas acima, em publicação do dia 29 de março de 1913, onde o advogado transcreve o ofício recebido por Aristides na época de sua saída. Tal ofício pode significar uma pista sobre a provável campanha de difamação a respeito do carregador:

Tendo em tempo alguém feito referências pouco lisonjeiras ao nosso bom companheiro Aristides Figueira de Souza, procurando malquistá-lo no meio do operariado, pretendendo fazer crer que ele ficou mal no meio de seus ex-companheiros de classe, na associação de que foi ele o iniciador e o seu primeiro presidente, e nós querendo ter uma ocasião de dar um desmentido formal a essas infâmias assacadas contra esse digno companheiro, para aqui transcrevemos hoje um ofício que o mesmo recebeu em 1908, quando ele se retirou daquela associação. A publicação desse ofício há de por força destruir as calúnias movidas contra esse companheiro, cujo prestígio no seio da classe é grande, a ponto de despertar ciúmes aos que não sabem se impor. Eis o ofício: "Ilm. ${ }^{\circ}$ Snr. Aristides F. de Souza, saudações.

40 Na edição de 18 de março de 1909 do Correio da Manhã, é possível verificar que nesse momento o advogado da entidade era Oscar da Rocha Cardoso.

41 A Época, Rio de Janeiro, 18 mar. 1913, p. 6. 
Competentemente autorizado pelo Snr. Francisco Guilherme das Chagas, presidente desta associação, tenho a cientificar-lhe que a Assembleia deliberou que se nomeasse uma comissão afim de sindicar se com efeito S. S. se achava coagido no trabalho. A mesma comissão informando se teve ciência de que S.S. só não trabalhava o dia que não queria, portanto, resolveu devolver os seus documentos, convicta da sua inocência em face do que éramos sabedores. Quanto à liberdade do cartão para o trabalho, a mesma Assembleia nada deliberou. É tudo o que tenho a dizer-lhe a tal respeito, o autorizando a fazer desta resposta o uso que lhe convier. Paz e Justiça - José Cardoso de Moraes Rego, $1^{\circ}$ Secretário. Rio de Janeiro, 22 de Janeiro de 1908". ${ }^{4}$

Sabemos que a perseguição política por parte da patronal era bastante recorrente naquele período, além dos vários mecanismos de deslegitimação e desmobilização do movimento dos trabalhadores através de campanhas públicas de difamação contra os militantes e dirigentes operários e, ao que parece, a expulsão de Aristides acontece com esse propósito. No artigo abaixo, Evaristo confirma essa tática usada por parte da polícia e do patronato desde o ano de 1906, que acusavam algumas lideranças do sindicato de serem indivíduos "estranhos à classe", após a greve daquele ano:

Nunca se ofereceu melhor ocasião para ser feita a prova da parcialidade ou da imparcialidade da polícia perante esse conflito industrial que vem sendo travado, desde algum tempo, entre patrões e operários, no comércio de café. Deram os jornais notícia de um abaixo-assinado que anda correndo as casas dos ensacadores e comissários no qual se fazem alusões diretas a nossa humilde pessoa e à gloriosa associação, que em agosto último nos chamou para seu advogado. Há (para exemplo) no dito documento períodos desta qualidade: "Os trabalhadores dos armazéns de café encarregados dos serviços de carga, descarga, baldeação e ensaque de café sempre viveram satisfeitíssimos com a sua situação e com os proventos que Ihes advinham do seu trabalho. Se alguma vez apresentaram reclamações, fizeram-no sem imposições, e por isso mesmo atendidas com toda a solicitude quando eram reconhecidamente justas. Ultimamente, porém, indivíduos estranhos à classe, iludindo os trabalhadores com promessas irrealizáveis, conseguiram que se fundasse uma sociedade pretextada indispensável para defender e advogar os interesses destes últimos." Note-se que do tal papel constam os grifos. Chega a ser cruel a ironia dos seus signatários quando descrevem a satisfação enorme, a felicidade extraordinária em que viviam mergulhados os trabalhadores! Tudo isso para atirar às costas de um humilde advogado - a honrosa responsabilidade da organização operária. Pois bem, usando da linguagem com que nos atacam, diremos: - É MENTIRA, E MENTIRA ODIOSA, ESSA QUE RESULTA DAS FRASES TRANSCRITAS, E DESAFIAMOS A QUALQUER HOMEM SÉRIO DO COMÉRCIO DE CAFÉ A CONTESTAR O QUE VAMOS ESCREVER. A tão malsinada e malquistada Sociedade de Resistência dos Trabalhadores em Trapiche e Café nasceu do seio da União dos Operários Estivadores, em abril de 1905. Foram seus fundadores, entre outros, o atual presidente Aristides Figueira de Souza e o procurador Arthur Paulo da Silva, ambos carregadores de café. Antes de sermos chamados para advogar os interesses da dita agremiação operária - o que somente se deu, como dissemos, em agosto deste ano - já fora seu patrono o distinto profissional forense e conhecido homem de letras dr. Silva Marques. Eis como, em breves traços, se destrói, mais uma vez, a estranha balela de termos sido inventores da atual organização operária... A verdade é que, antes dessa nossa volta para a atividade da propaganda

42 A Época, Rio de Janeiro, 29 mar. 1913, p. 6. 
socialista, já existiam a União dos Operários Estivadores, que tem quase o feitio e o funcionamento de um sindicato; a Sociedade União dos Foguistas que, com outros advogados, já pleiteara importantes causas; a referida e sempre atacada Sociedade dos Carregadores; a dos Trabalhadores em Carvão e Mineral, que também tivera anteriormente outros advogados. Ao certo, a única diferença entre a situação desses ilustres colegas e a nossa consiste em termos entrado na liça com os nossos francos ideais socialistas e não nos considerarmos advogado judiciário, e sim um trabalhador intelectual, que experimenta, com serenidade, a aplicação do sistema sindicalista no Brasil. Daí, dessa diferença de situações, nascem o despeito, a raiva, o ódio, a guerra contra nós agitados por esses que sentem diminuição dos seus fartos lucros e temem a ação do operariado consciente e de olhos abertos. Líquido fica este ponto, de caráter todo pessoal, e a ele não voltaremos, salvo o caso de alguém (não anônimo) ousar desmentir qualquer dos fatos por nós alegados. Indaguemos mais uma vez: que querem agora os patrões do café? Eles não o dizem claramente, mas dão a entender no tópico do abaixo-assinado em que assim se exprimem: "Manda a verdade que declaramos, Exm. ${ }^{\circ}$ Sr. Dr. Chefe de Polícia, que todas as exigências por parte desses homens tem sido por nós aceitas, pois, do contrário, seria para nós a paralisação do serviço, visto como não se encontra quem queira substituir os trabalhadores congregados, receosos das agressões à mão armada tantas vezes prometidas e não raramente executadas. Isto, Exm. ${ }^{\circ}$ Sr., porque até há bem pouco tempo faltou aos não grevistas o amparo da polícia para garantir-lhes a vida." Para quem sabe que não se deram as aludidas agressões; para quem, por observação direta, reconhece que a maioria absoluta dos carregadores, se não sua totalidade, pertence hoje à sociedade operária - é claro o intuito dos signatários do estranho documento. ELES QUEREM VER SE, COM AJUDA DA POLÍCIA, QUEBRAM OS PACTOS E CONVENÇÕES QUE ACEITARAM LIVREMENTE. Cumpra a alta autoridade, para a qual apelam, proceder, como esperamos, com essa criteriosa imparcialidade que a natureza das suas funções determina e o regime democrático exige. Aguardemos os fatos. ${ }^{43}$

Como esclarece o advogado, o patronato junto à polícia criou uma política aberta de repressão aos trabalhadores e, em especial, trabalhadores militantes, fazendo o uso de medidas que tinham como objetivo fragmentar a categoria, criando conflitos entre os próprios operários. Dizer que "indivíduos estranhos à classe" manipulavam os trabalhadores com ideias irrealizáveis, era claramente uma tática de atribuir aos trabalhadores (os nacionais em especial) uma suposta passividade frente aos conflitos contra os patrões e, portanto, significava dizer também que qualquer forma de organização política mais desenvolvida era alheia aos interesses dos mesmos e deveria ser, portanto, rejeitada.

Nesse sentido, é evidente a forte influência dos trabalhadores europeus em todo o processo de organização e sindicalização dos trabalhadores portuários no Rio de Janeiro e, por outro lado, as reações do governo junto à classe capitalista frente a essa intensa interferência, que não foi prevista com o projeto de vinda dos imigrantes nas décadas anteriores. Sendo assim, a lei de deportação dos trabalhadores estrangeiros que se envolvessem na política local criada em 1907 consistia em uma medida desesperada por parte dos patrões e governos frente a esse quadro de intensa ebulição política que se alastrava entre os trabalhadores do mundo todo, incluindo o Brasil.

43 A Época, Rio de Janeiro, 29 dez.1906, edição 01996, p. 3. 
É importante refletir, no entanto, sobre distintas possibilidades acerca desses elementos e sujeitos envolvidos ao inseri-los dentro de um contexto e espaço repleto de disputas políticas como um sindicato de trabalhadores. Sabemos que em qualquer instrumento de organização operária existem inúmeras divergências e conflitos em movimento, e o que pode ter motivado o afastamento do ex-presidente da associação poderia estar diretamente ligado a tais disputas políticas que não pudemos ter ciência nesta pesquisa.

Assim, dentro de nossos objetivos traçados para este trabalho, verificamos que, se por um lado a ingerência dos militantes europeus já havia sido insinuada pelos pesquisadores que se debruçaram sobre a história da Resistência anteriormente, tal fato em específico nos mostra que, além dos valores socialistas terem inserção de forma orgânica entre os trabalhadores brasileiros e descendentes de escravizados no período, esses mesmos militantes que se articulavam politicamente buscando o avanço no processo de sindicalização dos portuários atuavam simultaneamente em outras frentes, como na luta por moradias, na construção de ligas operárias na cidade e na organização do $4^{\circ}$ Congresso da Confederação Operária Brasileira (COB).

Não se trata, todavia, de negar o legado e as várias contribuições enraizadas e deixadas pelos trabalhadores escravizados e libertos no setor portuário, que, inclusive, enfatizamos ao longo do trabalho. Mas, trata-se de identificar e reconhecer a relação e integração entre as diferentes concepções de luta e resistência provindas desses distintos setores que, numa relação conflituosa e repleta de contradições, deu origem à Sociedade Resistência. Assim, ainda que de forma difusa, apesar dos conflitos no cotidiano existentes entre os associados, a atuação da entidade apontava para a unidade entre os trabalhadores e a não discriminação ou divisão entre esses sujeitos, fossem eles brasileiros, estrangeiros, brancos ou negros. Nesse sentido, pudemos perceber que, embora a questão racial estivesse bastante presente no discurso e atuação do sindicato - que relembrava e fazia alusão em vários momentos às condições de trabalho durante a escravidão em comparação às condições daquele período -, tal elemento era colocado de forma associada à questão de classe, essa situada de forma bastante explícita pelos seus integrantes.

Recebido em 31/10/2019

Aprovado em 07/02/2020 